\title{
Intracerebral hemorrhage: update and future directions
}

\author{
Hemorragia intracerebral: atualização e direções futuras \\ Eva ROCHA', Carolina ROUANET', Danyelle REGES', Vivian GAGLIARDI', \\ Aneesh Bhim SINGHAL2 , Gisele Sampaio SILVA',3
}

\begin{abstract}
Intracerebral hemorrhage $(\mathrm{ICH})$, defined as bleeding into the brain parenchyma, is a significant public health issue. Although it accounts for only 10 to $15 \%$ of strokes, it is associated with the highest morbidity and mortality rates. Despite advances in the field of stroke and neurocritical care, the principles of acute management have fundamentally remained the same over many years. The main treatment strategies include aggressive blood pressure control, early hemostasis, reversal of coagulopathies, clot evacuation through open surgical or minimally invasive surgical techniques, and the management of raised intracranial pressure.
\end{abstract}

Keywords: Cerebral Hemorrhage; Stroke; Critical Care.

\section{RESUMO}

A hemorragia cerebral é definida como um sangramento no parênquima cerebral e representa um importante problema de saúde pública. Ela corresponde a 10 a 15\% das causas de AVC e está associada a altas taxas de morbimortalidade. Apesar dos avanços no campo do AVC e dos cuidados neurocríticos, os princípios do manejo agudo permaneceram fundamentalmente os mesmos por muitos anos. As principais estratégias de tratamento incluem controle agressivo da pressão arterial, hemostasia precoce, reversão de coagulopatias, evacuação do coágulo por meio de técnicas cirúrgicas abertas ou cirúrgicas minimamente invasivas e gerenciamento da pressão intracraniana elevada.

Palavras-chave: Hemorragia Cerebral; Acidente Vascular Cerebral; Cuidados Críticos.

\section{SEARCH STRATEGY}

A PubMed search for articles published up to June 2019 was performed using the terms "intracerebral hemorrhage" [Title] and ("spontaneous" [Title/Abstract]), which turned out 1,102 articles. Additionally, the reference lists of the most recent guidelines on the management of spontaneous intracerebral hemorrhage were searched. Articles with at least one abstract in English or Portuguese were included.

\section{BACKGROUND}

Intracerebral hemorrhage (ICH) is defined as bleeding into the brain parenchyma that may extend into the ventricles and, less frequently, the subarachnoid and subdural spaces ${ }^{1}$. It accounts for 10 to $15 \%$ of all causes of stroke and is associated with the highest mortality rates (around $35 \%$ at 7 days and $59 \%$ at 1 year) ${ }^{1,2,3}$. The annual incidence of 10 to 30 per 100,000 inhabitants has remained stable in the last three decades ${ }^{1,4}$. Although there was a $50 \%$ decrease

\footnotetext{
1 Universidade Federal de São Paulo, Hospital São Paulo, Departamento de Neurologia e Neurocirurgia, São Paulo SP, Brazil.

${ }^{2}$ Massachusetts General Hospital, Stroke Service, Department of Neurology, Boston MA, USA.

${ }^{3}$ Hospital Israelita Albert Einstein, Academic Research Organization, São Paulo SP, Brazil.

Eva ROCHA (iD https://orcid.org/0000-0002-0981-3919; Carolina ROUANET (iD https://orcid.org/0000-0002-5667-6523;

Danyelle REGES (D) https://orcid.org/0000-0002-7699-2806; Vivian GAGLIARDI (ID) https://orcid.org/0000-0003-3182-5147;

Aneesh Bhim SINGHAL (iD) https://orcid.org/0000-0002-2641-5277; Gisele Sampaio SILVA (iD) https://orcid.org/0000-0002-3247-3123

Correspondence: Eva Rocha; E-mail:eva.rochac@gmail.com

Conflict of interests: Gisele Silva is the main investigator in the ETHICS study.

Authors' contributions: Dr. Eva Rocha conceptualized and drafted the manuscript; Dr. Carolina Rouanet drafted the manuscript; Dr. Danyelle Reges drafted the manuscript; Dr. Vivian Gagliardi drafted the manuscript; Dr. Aneesh Bhim Singhal revised the manuscript for intelectual content; Dr. Gisele Sampaio Silva conceptualized and revised the manuscript for intellectual content.

Support: Dr. Eva Rocha's visiting scholarship at Massachusetts General Hospital and Harvard Medical School, Boston, was sponsored by the Capes Foundation, Ministry of Education, Brazil (grant No. 88881.133101/2016-01).
}

Received on February 16, 2020; Received in its final form on February 16, 2020; Accepted on April 08, 2020. 
in the incidence of ICH in patients below 60 years of age, an there was an $80 \%$ increase in patients above 74 years of age 4 . Advances in the field of stroke and neurocritical care have reduced mortality within 30 days - after ICH in the past years, although early case-mortality rates (within 48 hours) have not improved ${ }^{5}$.

Spontaneous (non-traumatic) ICH can be primary or secondary. Primary ICH represents 78 to $88 \%$ of cases and originates from spontaneous rupture of small vessels, usually from chronic hypertension and cerebral amyloid angiopathy $(\mathrm{CAA})^{1,6}$. Secondary ICH results from ruptured vascular abnormalities such as arteriovenous malformations (AVM), cavernomas, and aneurysms. According to location, hematomas can be classified as deep (37\%), lobar (49\%), infratentorial (9\%) or of undetermined location $(5 \%)^{1,7}$. Treatment strategies include blood pressure control, reversal of coagulopathy and neurosurgery in selected cases ${ }^{8}$.

\section{ETIOPATHOLOGY}

The main risk factors for ICH are hypertension, anticoagulation use, heavy alcohol consumption, family history of ICH, personal history of ischemic stroke, low educational levels, and APOE $\varepsilon 2$ or $\varepsilon 4$ genotype ${ }^{9}$. Alternatively, reduced prevalence of ICH was found in patients with a history of hypercholesterolemia or moderate alcohol consumption (less than two glasses a day ${ }^{10}$. Hypercholesterolemia has been described in many studies as a protective factor, although statin use has not been related to a higher ICH risk and can even reduce it ${ }^{11}$.

\section{Primary intracerebral hemorrhage}

The main primary etiologies leading to vasculopathy and cerebral hemorrhage are hypertension and CAA. Chronic hypertension induces lipohyalinosis of small perforating arteries, leading to deep hemorrhages that frequently extend to the ventricles ${ }^{1}$. In 1868, Charcot and Bouchard attributed intracerebral bleeding to the rupture of dilated arteriolar wall (microaneurysms). These morphological entities were posteriorly identified as subadventitious hemorrhages or extravascular thrombi consequences of endothelial damage from the hematoma. The main topographies of hypertensive ICH are in the territories of the small 'penetrating' arteries originating off the stems of the main cerebral arteries (the putamen, thalamus, pons, and cerebellum $)^{1}$.

Amyloid angiopathy is the most common etiology in patients over 70 years of age with lobar $\mathrm{ICH}^{4}$. Progressive deposition of beta-amyloid peptide on the wall of leptomeningeal and cortical vessels reduces their complacency, leading to a spectrum of hemorrhagic manifestations including cerebral microbleeds (CMB), cortical superficial siderosis (cSS), and intracerebral hemorrhage. The main characteristics of CAA are the presence of lobar, cortical or cortical-subcortical hemorrhage, CMB, and cSS in patients above 55 years of age (Figure 1) $)^{12,13}$. The Boston criteria were proposed in 1995 and modified in 2010 to estimate the chance of CAA in patients with ICH (Table 1) $)^{12,14}$.

\section{Secondary intracerebral hemorrhage}

An important and increasing cause of secondary ICH is anticoagulation, which significantly increases the risk of intracranial hemorrhage, hematoma expansion, and

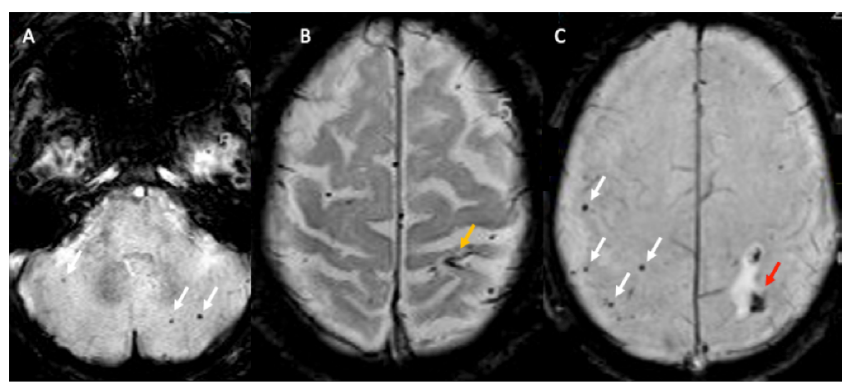

Figure 1. Imaging findings in cerebral amyloid angiopathy. Susceptibility weighted magnetic resonance imaging in patient with cerebral amyloid angiopathy depicting: (A) cerebellar microbleeds (white arrows), (B) superficial siderosis (yellow arrow), and (C) lobar intracerebral hemorrhage (red arrow) and cortico-subcortical microbleeds (white arrows).

Table 1. Modified Boston criteria for the diagnosis of amyloid angiopathy in patients with intracerebral hemorrhage.

\begin{tabular}{|c|c|}
\hline \multicolumn{2}{|r|}{ Modified Boston criteria } \\
\hline Definite CAA & $\begin{array}{l}\text { Full postmortem examination demonstrating: } \\
\text { - Lobar, cortical or cortical-subcortical } \\
\text { hemorrhage } \\
\text { - Severe CAA with vasculopathy } \\
\text { - Absence of other diagnostic lesion }\end{array}$ \\
\hline $\begin{array}{l}\text { Probable CAA } \\
\text { with supporting } \\
\text { pathology }\end{array}$ & $\begin{array}{l}\text { Clinical data and pathological tissue } \\
\text { (evacuated hematoma or cortical biopsy) } \\
\text { demonstrating: } \\
\text { - Lobar, cortical or cortical-subcortical } \\
\text { hemorrhage (including ICH, CMB or cSS) } \\
\text { - Some degree of CAA in specimen } \\
\text { - Absence of other diagnostic lesion }\end{array}$ \\
\hline Probable CAA & $\begin{array}{l}\text { Clinical data and MRI or CT demonstrating: } \\
\text { - Multiple hemorrhages (ICH, CMB) restricted } \\
\text { to lobar, cortical or cortical-subcortical } \\
\text { regions (cerebellar hemorrhage allowed) or } \\
\text { single lobar, cortical or cortical-subcortical } \\
\text { hemorrhage and cSS (focal or disseminated) } \\
\text { - Age } \geq 55 \text { years } \\
\text { - Absence of other cause of hemorrhage* }\end{array}$ \\
\hline Possible CAA & $\begin{array}{l}\text { Clinical data and MRI or CT demonstrating: } \\
\text { - Single lobar, cortical or cortical-subcortical } \\
\text { ICH, CMB, or cSS (focal or disseminated) } \\
\text { - Age } \geq 55 \text { years } \\
\text { - Absence of other cause of hemorrhage* }\end{array}$ \\
\hline
\end{tabular}

CAA: cerebral amyloid angiopathy; CMB: cerebral microbleed; cSS: cortical superficial siderosis; CT: computed tomography; $\mathrm{ICH}$ : intracerebral hemorrhage; MRI: magnetic resonance imaging.

*Other causes of hemorrhage (differential diagnosis of lobar hemorrhages): antecedent head trauma, hemorrhagic transformation of an ischemic stroke, arteriovenous malformation, hemorrhagic tumor, warfarin therapy with international normalization ratio $>3$, and vasculitis. 
mortality ${ }^{15}$. Warfarin use may increase the risk of ICH in 2 to 5 fold, depending on the intensity of anticoagulation ${ }^{16}$. Congenital or acquired coagulation factor deficiencies, thrombocytopenic disorders, and lymphoproliferative disorders are less frequent etiologies ${ }^{17}$.

Structural lesions are potentially treatable causes of ICH and should be searched for with vascular imaging studies, such as computerized tomographic angiography (CTA). Up to $10 \%$ of brain aneurysms can result in intraparenchymal bleeding. Arteriovenous malformations, angiomatous cavernomas, and tumors may also be involved in ICH development ${ }^{7}$. Other conditions include brain neoplasms or metastasis, cerebral venous thrombosis, and reversible cerebral vasoconstriction syndromes ${ }^{18}$.

\section{SMASH-U classification}

A tool for etiological classification published in 2012 entitled SMASH-U, classifies ICH according to its different etiologies: structural lesions, related to medications, amyloid angiopathy, systemic diseases, hypertension, and undetermined (Table 2) $)^{19,20}$.

\section{DIAGNOSIS}

Patients with ICH are usually admitted to the hospital with sudden onset of focal neurological deficits, severe acute

Table 2. Structural lesion, Medication, Amyloid angiopathy, Systemic/other disease, Hypertension, Undetermined etiologic classification of intracerebral hemorrhage.

\begin{tabular}{|c|c|}
\hline \multicolumn{2}{|c|}{ Etiologic classification SMASH-U } \\
\hline $\begin{array}{l}\text { S - Structural } \\
\text { lesion }\end{array}$ & $\begin{array}{l}\text { Image or pathology confirming structural } \\
\text { vascular malformation diagnosed on the } \\
\text { site of } \mathrm{ICH}\end{array}$ \\
\hline M - Medication & $\begin{array}{c}\text { Warfarin use with INR greater than or equal } \\
\text { to } 2 \text {, direct oral anticoagulants within } 3 \\
\text { days, therapeutic IV heparin, or systemic } \\
\text { thrombolysis }\end{array}$ \\
\hline $\begin{array}{l}\text { A - Amyloid } \\
\text { angiopathy }\end{array}$ & $\begin{array}{l}\text { Lobar, cortical or subcortical hemorrhage } \\
\text { and age } \geq 55 \text { years }\end{array}$ \\
\hline $\begin{array}{l}\text { S - Systemic } \\
\text { disease/other }\end{array}$ & $\begin{array}{c}\text { Systemic disease or other } \mathrm{ICH} \text { etiology } \\
\text { except from anticoagulation, hypertension } \\
\text { or amyloid angiopathy }\end{array}$ \\
\hline H - Hypertension & $\begin{array}{c}\text { Deep or infratentorial hemorrhage or pre- } \\
\text { ICH hypertension, defined as: } \\
\text { a) Most recent pre-ICH blood pressure } \\
\geq 160 \times 100 \mathrm{mmHg} \\
\text { b) Mention of elevated blood pressure } \\
\text { prior to ICH by patient, relative or medical } \\
\text { records, with left ventricular hypertrophy as } \\
\text { a biomarker of hypertension } \\
\text { c) Any use of blood pressure medication } \\
\text { prior to ICH }\end{array}$ \\
\hline U - Undetermined & None of the above \\
\hline
\end{tabular}

SMASH-U: Structural lesion, Medication, Amyloid angiopathy, Systemic/ other disease, Hypertension, Undetermined; ICH: intracerebral hemorrhage; INR: international normalized ratio. headaches, nausea, vomiting, seizures, decreased level of consciousness, and high blood pressures. Brain imaging is essential for diagnostic confirmation and differentiation from ischemic stroke ${ }^{8}$. Both non-contrasted head CT and MRI are highly sensitive for the detection of acute bleeding, although MRI (gradient-eco and susceptibility sequences) is more sensitive in detecting prior hemorrhage ${ }^{8}$. Hematoma volume can be estimated using the $\mathrm{ABC} / 2$ method ( $\mathrm{A}$, maximal hematoma diameter on axial imaging; $\mathrm{B}$, maximal hematoma diameter perpendicular to $\mathrm{A}$; and $\mathrm{C}$, number of axial slices with the hematoma multiplied by the slice thickness [slices with $<25 \%$ of hematoma volume are ignored, slices with 25 to $75 \%$ of hematoma volume count as 0.5 , and those with $>75 \%$ of hematoma volume count as 1]) (Figure 2) ${ }^{21}$.

Imaging and clinical data, such as the absence of hypertension and atypical location, may help identify patients with possible structural etiologies that require further investigation and vascular imaging ${ }^{22,23}$. MRI findings indicating secondary etiologies include the presence of flow-voids in arteriovenous malformations, lobar microbleeds in CAA and contrast enhancement in tumors or inflammatory etiologies. If the first MRI is normal in suspected cases, a follow-up imaging within four to six weeks is required8.

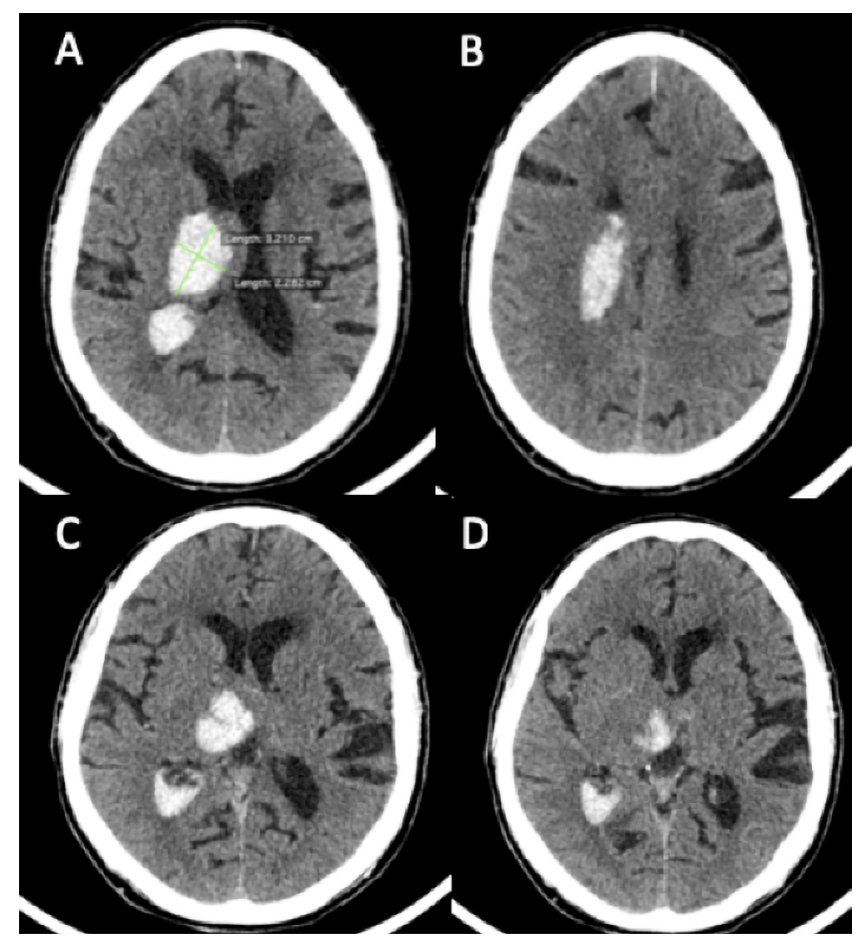

Figure 2. Hematoma volume estimation. (A) Non-contrasted computed tomography axial slice with maximal hematoma area with green lines indicating the maximum diameter (A line) measuring $3.21 \mathrm{~cm}$ and its maximum perpendicular diameter (B line) measuring $2.26 \mathrm{~cm}$. (B) Axial slice $10 \mathrm{~mm}$ cranial to A shows hematoma area of $75-100 \%$ of the reference slice. (C) Axial slice $10 \mathrm{~mm}$ caudal to A shows hematoma area of $25-75 \%$ of the reference slice. (D) Axial slice $20 \mathrm{~mm}$ caudal to A shows hematoma area below $25 \%$ of the reference slice. Thus, the estimated hematoma volume is $2.26 \times 3.21 \times(1.0+0.5+0.0) / 2=5.44 \mathrm{~mL}$. 
Vascular imaging such as CTA, MR-angiography and digital subtraction angiography can assist in etiological definition ${ }^{8}$. Imaging findings indicating vascular abnormalities include the presence of subarachnoid hemorrhage, dilated vessels, perihematoma calcifications, hyperintensity within venous sinus or cortical veins, unusual hematoma shape, unusual location, and disproportionally large peri-hematoma edema ${ }^{8,23}$.

\section{Hematoma expansion}

Hematoma expansion is frequently seen on followup imaging. Patients presenting early symptom onset and receiving anticoagulated are at higher risk for hematoma expansion. The presence of expansion is associated with a worse prognosis, thus preventing it is one of the treatment goals $^{8,24}$. Several tools have been proposed to predict hematoma expansion, including the BRAIN algorithm (Table 3), the HEP and BAT scores, ${ }^{24,25}$ and image markers such as "spot sign", "leakage sign”, "island sign”, "blend sign”, "black hole sign", and "satellite sign". The "spot sign" is detected through CTA and is characterized by a spot of contrast enhancement inside the hematoma. The "leakage sign" is more sensitive than the spot sign and the image is acquired 5 minutes after CTA (late phase). Images from both arterial and late phases are evaluated and an increase in more than $10 \%$ of Hounsfield units between images determines a positive "leakage sign"26. The "island sign", "blend sign”, "black hole sign", and "satellite sign” are seen in the non-contrasted head-CT (Figure 3). The "island sign" is defined as scattered small hematomas apart from the main hematoma and the "blend sign" is defined as blending of a relatively hypoattenuating area with adjacent hyperattenuating region within a hematoma. The "black hole sign" is defined as a relatively hypoattenuating area (black hole) encapsulated within the hyperattenuating hematoma

Table 3. The BRAIN algorithm for hematoma expansion.

\begin{tabular}{lc}
\hline \multicolumn{2}{c}{ "BRAIN" score } \\
\hline \\
B- Baseline ICH volume & $\begin{array}{c}10-20=5 \\
>20=7\end{array}$ \\
& Yes $=4$ \\
R- Recurrent ICH & Yes $=6$ \\
A - Anticoagulation with & No $=0$ \\
warfarin at onset & Yes $=2$ \\
I - Intraventricular extension & $\leq 1=5 ; 1-2=4 ; 2-3=3 ;$ \\
N- Number of hours to baseline & $3-4=2 ; 4-5=1 ;>5=0$ \\
computed tomography & Number of points and \\
& risk of expansion: \\
& $0-5: 3.4-7.7 \%$ \\
& $6-10: 11.3-23.1 \%$ \\
Total & $11-15: 27.2-46.7 \%$ \\
& $16-20: 52.1-71.9 \%$ \\
& $20-24: 76.0-85.8 \%$ \\
\hline
\end{tabular}

$\mathrm{ICH}$ : intracerebral hemorrhage. and the "satellite sign" is defined as small (maximal diameter $<10 \mathrm{~mm}$ ) hemorrhage close to but completely isolated from the main hemorrhage in at least a single slice $\mathrm{e}^{27,28,29,30,31}$.

\section{Diffusion-weighted imaging abnormalities}

The occurrence of diffusion-weighted imaging (DWI) abnormalities is described in 15 to $46 \%$ of patients with ICH, and lesions can be found in perihematomal or remote regions. The presence of DWI lesions in the perihematomal region is associated with higher hematoma volumes, whereas remote lesions are associated with lobar hemorrhages, leukoaraiosis, higher rates of anti-platelet medication, amyloid angiopathy, previous ICH, and atrial fibrillation ${ }^{32,33,34,35,36,37,38}$.

Potential embolic sources were described in patients with DWI lesions, such as atrial fibrillation and performance of catheter angiography before $\mathrm{MRI}^{32}$. Another possible explanation for this phenomenon is the occurrence of hyperacute and spontaneous hemorrhage following an ischemic stroke of embolic etiology with recanalization ${ }^{39}$.

There is probably a sum of mechanisms influencing the appearance of these ischemic lesions in the setting of acute ICH. Patients with brain hemorrhage usually have a vulnerable microvasculature due to chronic hypertension or amyloid angiopathy, that suffer from an acute state of blood pressure variability, raised intracranial pressure (ICP) and failure in autoregulation, which may culminate in acute cerebral ischemia. Additionally, patients could present with other risk factors for ischemic stroke and even embolic sources causing the ischemia seen on MRI (Figure 4) ${ }^{35}$.

\section{MEDICAL TREATMENT}

ICH is a medical emergency and requires prompt diagnosis and management. Early deterioration occurs in up to a third of patients in the first hours ${ }^{8,40}$. Initial treatment starts with clinical assessment, airway protection, and hemodynamic

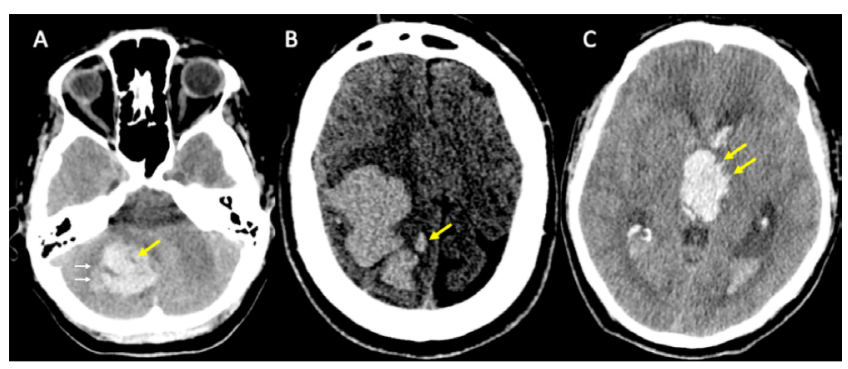

Figure 3. Non-contrasted computed tomography imaging of acute intracerebral hemorrhage with expansion signs. Non-contrast computed tomography of acute intracerebral hemorrhage. (A) Cerebellar intracerebral hemorrhage with "blend sign" (white arrows) and "black-hole sign" (yellow arrow). (B) Lobar intracerebral hemorrhage with "satellite sign" (yellow arrow). (C) Deep intracerebral hemorrhage with "island sign" (yellow arrows). 


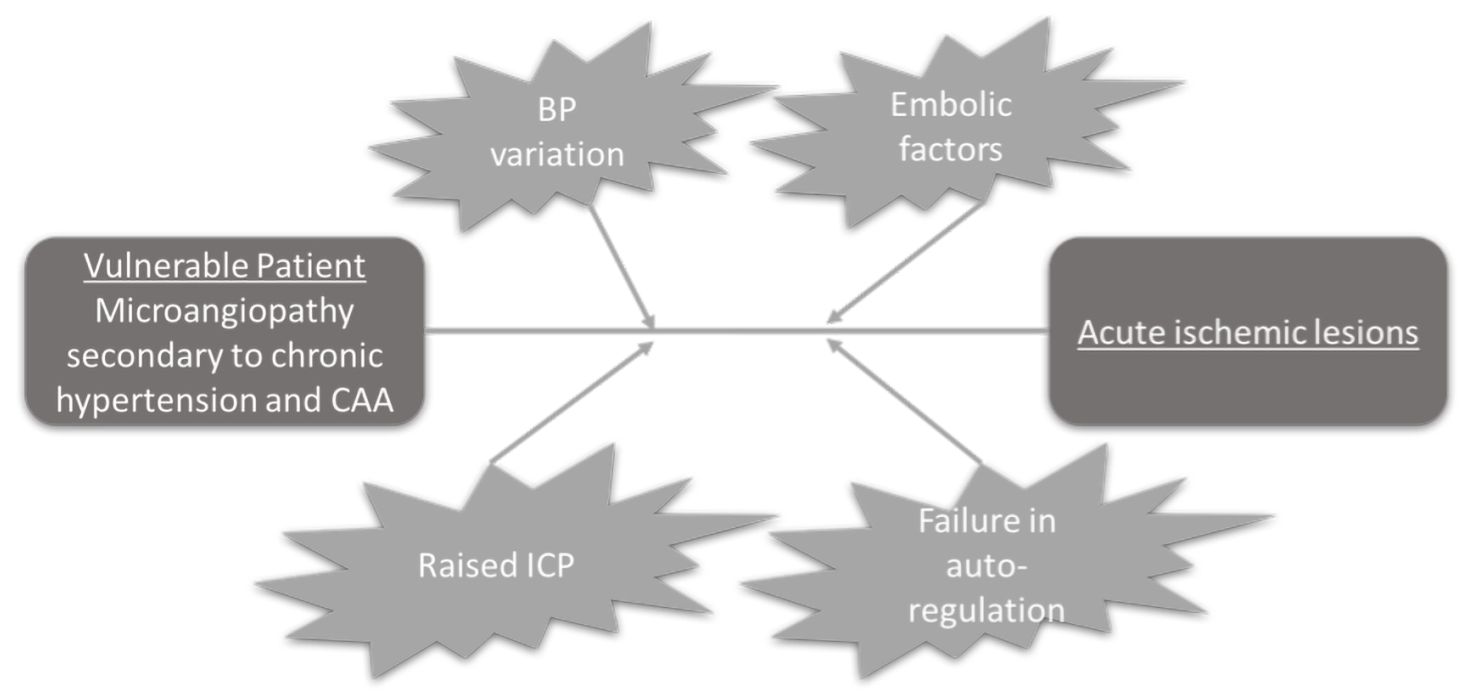

Adapted from Prabhakaran, et al. Stroke. 2012

Figure 4. Possible mechanisms leading to ischemia in intracerebral hemorrhage.

stabilization $^{40}$. Neuroimaging must be performed as soon as possible in order to differentiate ischemic from hemorrhagic stroke and initiate proper treatment ${ }^{8}$. Treatment should preferably be carried out in a tertiary center, with a multidisciplinary team of neurologists, neuroradiologists, neurosurgeons and a neurointensive care unit ${ }^{8}$. Acute treatment includes blood pressure management, coagulopathy reversal, neurosurgical interventions for hematoma evacuation, external ventricular drainage (EVD) and ICP monitoring.

\section{Blood pressure management}

Intensive blood pressure management is thought to reduce hematoma expansion and improve functional outcomes $^{41}$. The Intensive Blood Pressure Reduction in Acute Cerebral Hemorrhage (INTERACT) study showed that patients with aggressive blood pressure management with systolic blood pressures (SBP) at a target of $140 \mathrm{mmHg}$ or less had lower hematoma growth ${ }^{42}$. The INTERACT2 study included 2,800 patients with acute $\mathrm{ICH}^{43}$. Although it did not reach statistical significance on its primary outcome, defined as moderately severe disability or less in 90 days, an ordinal analysis of modified Rankin scores showed improved functional outcomes with intensive blood pressure lowering ${ }^{43}$. Systolic blood pressure reduction to levels close to $140 \mathrm{mmHg}$ was safe and did not increase the risk of perihematomal ischemia $^{43}$. Because of this study, the current American Heart Association guidelines for the management of ICH suggests lowering systolic blood pressure to $140 \mathrm{mmHg}$ or less ${ }^{8}$.

In June 2016, the Anti-hypertensive Treatment of Acute Cerebral Hemorrhage II (ATACH-II ) study was published, comparing standard (SBP of $140-179 \mathrm{mmHg}$ ) to intensive (110-139 $\mathrm{mmHg}$ ) blood pressure management ${ }^{41,44}$. The study was interrupted due to futility after the inclusion of 1,000 patients ${ }^{44}$. At first glance, ATACH-II results seem conflicting with INTERACT2, since the "intensive" treatment was not superior to the "standard" one, but rather was associated with higher complication rates (especially kidney impairment). However, it was observed that the "standard" group maintained a mean SBP of about $140 \mathrm{mmHg}$, while the "intensive" group had a mean SBP of about $120 \mathrm{mmHg}^{41,44}$. The final conclusion was that "very intensive" blood pressure reduction with SBP levels below $120 \mathrm{mmHg}$ does not offer additional benefits when compared to "intensive" treatment with SBP levels around $140 \mathrm{mmHg}^{41,44}$.

\section{Reversal of coagulopathy}

Coagulation disorders are a common cause of intracerebral hemorrhage and should be promptly treated ${ }^{8}$. Reversal of anticoagulation in patients receiving vitamin $\mathrm{K}$ antagonists (warfarin) is achieved through intravenous vitamin K administration (10 mg), followed by fresh frozen plasma (FFP) or prothrombin complex concentrates (PCC). PCC is preferable in comparison to FFP due to its faster action and greater effectiveness $^{8,45}$. The INR target should be of 1.4 or less and its measurement should be repeated shortly after PCC administration. If the values are still above 1.4, FFP may be administered for greater INR reduction.

For patients with ICH using factor Xa inhibitors (rivaroxaban, apixaban, edoxaban) or thrombin inhibitors (dabigatran), treatment options include PCC, FEIBA or FVIIa. Activated charcoal may be used if ingestion occurred within 2 hours ${ }^{8,45}$. For direct reversal of dabigatran, idarucizumab $5 \mathrm{~g}$ IV in 2 doses or hemodialysis can be performed ${ }^{46}$. Andexanet, a reversal agent for factor Xa inhibitors, was recently approved by the Food and Drug Administration (FDA ${ }^{47}$.

In patients anticoagulated with unfractionated heparin (UFH), IV infusion must be immediately discontinued and protamine sulfate should be administered ( $1 \mathrm{mg}$ for every 100 UI of heparin given in the last 2-3 hours) at a maximum dosage of $50 \mathrm{mg}^{45}$. In case partial thromboplastin time (PTTa) remains 
elevated, protamine can be readministered at a dose of $0.5 \mathrm{mg}$ for every 100 units of $\mathrm{UFH}^{45}$. Low molecular weight heparin can be reversed with protamine sulfate or recombinant factor $\mathrm{VII}^{45}$. PCC and FFP are not recommended in these cases ${ }^{45}$. Platelet transfusion in patients using antiplatelet agents was proven ineffective and even harmful ${ }^{48}$. Hemostatic medications in ICH patients without coagulopathy have been proven ineffective. Factor VII and tranexamic acid did not improve survival or functional outcome after $\mathrm{ICH}^{49,50}$.

\section{Intensive care}

Pneumatic compression is indicated for deep venous thrombosis prevention until the documentation of bleeding cessation, when low molecular weight heparin (LMWH) or UFH can be initiated in prophylactic doses. Glycemic and temperature control are crucial, and dysglycemia and hyperthermia should be avoided ${ }^{8}$. Anti-seizure medication is solely indicated in the presence of seizure activity and continuous electroencephalogram (EEG) is recommended in patients with decreased level of consciousness not fully explained by the extent or location of the brain lesion ${ }^{8,40}$.

\section{SURGICAL TREATMENT}

Patients evolving with hydrocephalus should receive an EVD with ICP monitoring, especially if there is impaired consciousness. Cerebral perfusion pressure must be kept at 60-70 mmHg. Although studies have suggested the safety of intraventricular alteplase in patients with intraventricular hemorrhage, treatment efficacy is uncertain ${ }^{8}$. Patients with cerebellar hemorrhage and progressive neurological decline, brainstem compression or hydrocephalus should undergo hematoma evacuation ${ }^{40,45}$. Decompressive craniectomy with or without hematoma evacuation should be considered in comatose patients, in large hematomas with midline shifts or refractory elevated $\mathrm{ICP}^{8,40}$. Hematoma evacuation through minimally invasive surgery, endoscopic aspiration or early evacuation do not have proven efficacy ${ }^{8,51}$. The MISTIE III study prospectively evaluated minimally invasive surgery with thrombolysis for hematoma evacuation in patients with $\mathrm{ICH}$ volumes $\geq 30 \mathrm{~mL}$. Although the primary outcome (modified Rankin scores of 0-3 at 1 year) was negative, the subgroup of patients with residual hematoma of $\leq 15 \mathrm{~mL}$ or reduction of $\geq 70 \%$ had better functional outcomes and survival rates ${ }^{52}$. A summary of treatment approaches with management algorithm is depicted in Figure $5^{53}$.

\section{PROGNOSIS}

Baseline prognostic scoring systems are helpful in defining mortality risks. The most commonly used score worldwide is the ICH score (Table 4$)^{8,40}$. This scale

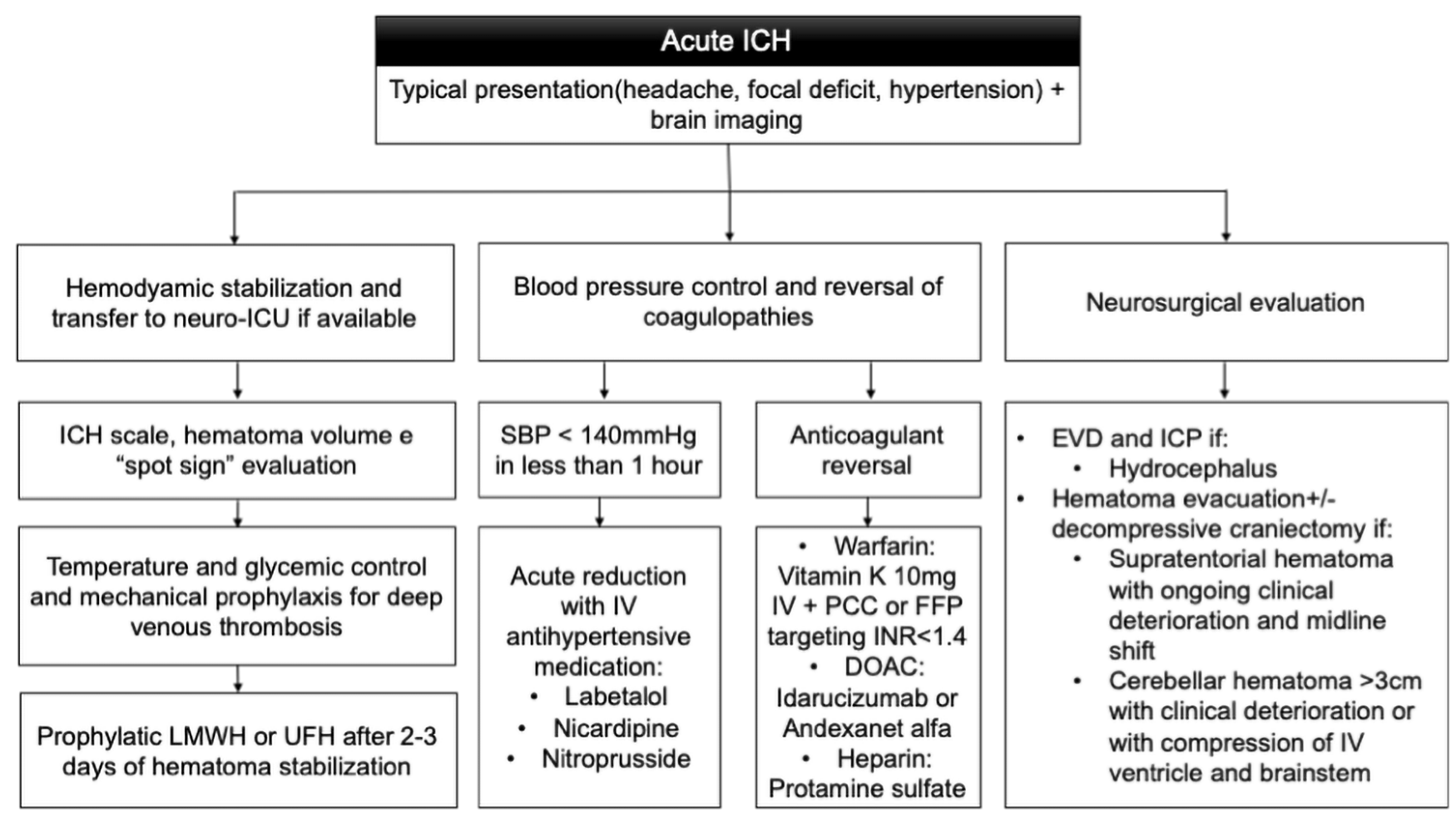

EVD: external ventricular drainage; FFP: fresh frozen plasma; ICH: intracerebral hemorrhage; ICU: intensive care unit; ICP: intracranial pressure; INR: international normalized ratio; IV intravenous; LMWH: low molecular weight heparin; PCC: prothrombin complex concentrate; SBP: systolic blood pressure; UFH: unfractionated heparin.

Figure 5. Acute intracerebral hemorrhage treatment algorithm 
Table 4. Intracerebral hemorrhage scale and prognosis.

\begin{tabular}{|c|c|c|}
\hline \multicolumn{3}{|c|}{$\mathrm{ICH}$ scale and prognosis } \\
\hline Glasgow Coma Scale & $\begin{array}{c}3-4 \\
5-12 \\
13-15\end{array}$ & $\begin{array}{l}2 \\
1 \\
0\end{array}$ \\
\hline Hematoma volume & $\begin{array}{l}\geq 30 \mathrm{~mL} \\
<30 \mathrm{~mL}\end{array}$ & $\begin{array}{l}1 \\
0\end{array}$ \\
\hline $\begin{array}{l}\text { Intraventricular } \\
\text { hemorrhage }\end{array}$ & $\begin{array}{l}\text { Yes } \\
\text { No }\end{array}$ & $\begin{array}{l}1 \\
0\end{array}$ \\
\hline Infratentorial origin & $\begin{array}{l}\text { Yes } \\
\text { No }\end{array}$ & $\begin{array}{l}1 \\
0\end{array}$ \\
\hline Age & $\begin{array}{l}\geq 80 \text { years } \\
<80 \text { years }\end{array}$ & $\begin{array}{l}1 \\
0\end{array}$ \\
\hline Total & $\begin{array}{c}0 \\
1 \\
2 \\
3 \\
4 \\
5 \text { and } 6\end{array}$ & $\begin{array}{l}30 \text {-day mortality: } 0 \% \\
\text { 30-day mortality: } 13 \% \\
\text { 30-day mortality: } 26 \% \\
\text { 30-day mortality: } 72 \% \\
\text { 30-day mortality: } 97 \% \\
\text { 30-day mortality: } 100 \%\end{array}$ \\
\hline
\end{tabular}

$\mathrm{ICH}$ : intracerebral hemorrhage.

stratifies 30-day mortality risk and varies from 0 to $6^{54}$. In the original study, mortality in patients scored 0 was $0 \%$, while patients with scores 4 or higher have mortality rates of almost $100 \%$ in the first 30 days $^{54}$. Since the publication of the ICH score in 2001, other mortality prediction scales have been developed. As an important limitation for these scales, patients who had withdrawal of care in the first days of admission were included in the analysis. Caregivers should be cautious when defining prognosis in ICH in order to avoid engaging a self-fulfilling prophecy. Consequently, waiting at least 24 hours before deciding to withdraw care is recommended ${ }^{8,55}$.

\section{FINAL REMARKS}

Intracerebral hemorrhage is a life-threatening acute neurological disorder requiring emergent treatment. Neuroimaging is imperative for diagnosis, etiological classification, prediction of hematoma growth, and prognosis. Although frequently detected, the mechanisms and clinical significance of acute DWI imaging are still uncertain. Treatment mainstays include blood pressure reduction and coagulopathy reversal, which should be promptly initiated. Surgical treatment with EVD insertion, hematoma evacuation or decompressive craniectomy is often necessary. The role of minimally invasive surgery is still uncertain, although recent studies have shown promising results.

\section{References}

1. Qureshi Al, Tuhrim S, Broderick JP, Batjer HH, Hondo H, Hanley DF. Spontaneous intracerebral hemorrhage. N Engl J Med. 2001 May;344(19):1450-60. https://doi.org/10.1056/ nejm200105103441907

2. van Asch CJ, Luitse MJ, Rinkel GJ, van der Tweel I, Algra A, Klijn CJ. Incidence, case fatality, and functional outcome of intracerebral haemorrhage over time, according to age, sex, and ethnic origin: a systematic review and meta-analysis. Lancet Neurol. 2010 Feb;9(2):167-76. https://doi.org/10.1016/S1474-4422(09)70340-0

3. Sacco S, Marini C, Toni D, Olivieri L, Carolei A. Incidence and 10year survival of intracerebral hemorrhage in a population-based registry. Stroke. 2009 Feb;40(2):394-9. https://doi.org/10.1161/ STROKEAHA.108.523209

4. Béjot Y, Cordonnier C, Durier J, Aboa-Eboulé C, Rouaud O, Giroud M. Intracerebral haemorrhage profiles are changing: results from the Dijon population-based study. Brain. 2013 Feb;136(Pt 2):658-64. https://doi.org/10.1093/brain/aws349

5. Béjot Y, Grelat M, Delpont B, Durier J, Rouaud O, Osseby GV, et al. Temporal trends in early case-fatality rates in patients with intracerebral hemorrhage. Neurology. 2017 Mar;88(10):985-90. https://doi.org/10.1212/WNL.0000000000003681

6. Martins ANN, De Figueiredo MM, Rocha OD, Fernandes MAF, Jeronimo SMB, Dourado ME. Frequency of stroke types at an emergency hospital in Natal, Brazil. Arq Neuro-Psiquiatr. 2007 Dec;65(4B):1139-43. https://doi.org/10.1590/s0004$282 \times 2007000700009$

7. Qureshi Al, Mendelow D, Hanley DF. Intracerebral haemorrhage. Lancet. 2009 May;373(9675):1632-44. https://doi.org/10.1016/ S0140-6736(09)60371-8
8. Hemphill III JC, Greenberg SM, Anderson CS, Becker K, Bendok BR, Cushman M, et al. Guidelines for the management of spontaneous intracerebral hemorrhage: a guideline for Healthcare Professionals from the American Heart Association/American Stroke Association. Stroke. 2015 Jul;46(7):2032-60. https://doi.org/10.1161/ STR.0000000000000069

9. Martini SR, Flaherty ML, Brown WM, Haverbusch M, Comeau ME, Sauerbeck LR, et al. Risk factors for intracerebral hemorrhage differ according to hemorrhage location. Neurology. 2012 Dec;79(23):227582. https://doi.org/10.1212/WNL.0b013e318276896f

10. Chen CJ, Brown WM, Moomaw CJ, Langefeld CD, Osborne J, Worrall BB, et al. Alcohol use and risk of intracerebral hemorrhage. Neurology. 2017 May;88(21):2043-51. https://doi.org/10.1212/ WNL.0000000000003952

11. Saliba W, Rennert HS, Barnett-Griness O, Gronich N, Molad J, Rennert G, et al. Association of statin use with spontaneous intracerebral hemorrhage. Neurology. $2018 \mathrm{Jul} ; 91$ (5):e400-e409. https://doi.org/10.1212/WNL.0000000000005907

12. Smith EE, Greenberg SM. Clinical diagnosis of cerebral amyloid angiopathy: validation of the Boston criteria. Curr Atheroscler Rep. 2003 Jul;5(4):260-6. https://doi.org/10.1007/s11883-003-0048-4

13. Linn J, Halpin A, Demaerel P, Ruhland J, Giese AD, Dichgans M, et al. Prevalence of superficial siderosis in patients with cerebral amyloid angiopathy. Neurology. 2010 Apr;74(17):1346-50. https://doi. org/10.1212/WNL.0b013e3181dad605

14. Greenberg SM, William Rebeck G, Vonsattel JPG, Gomez-Isla T, Hyman BT. Apolipoprotein E $\in 4$ and cerebral hemorrhage associated with amyloid angiopathy. Ann Neurol. 1995 Aug;38(2):254-9. https:// doi.org/10.1002/ana.410380219 
15. Flaherty ML, Kissela B, Woo D, Kleindorfer D, Alwell K, Sekar P, et al. The increasing incidence of anticoagulant-associated intracerebral hemorrhage. Neurology. 2007 Jan;68(2):116-21. https://doi. org/10.1212/01.wnl.0000250340.05202.8b

16. Hart RG, Boop BS, Anderson DC. Oral anticoagulants and intracranial hemorrhage: facts and hypotheses. Stroke. 1995 Aug;26(8):1471-7. https://doi.org/10.1161/01.str.26.8.1471

17. del Zoppo GJ, Mori E. Hematologic causes of intracerebral hemorrhage and their treatment. Neurosurg Clin N Am. 1992 Jul;3(3):637-58.

18. Topcuoglu MA, Singhal AB. Hemorrhagic reversible cerebral vasoconstriction syndrome: features and mechanisms. Stroke. 2016 Jul;47(7):1742-7. https://doi.org/10.1161/STROKEAHA.116.013136

19. Meretoja A, Strbian D, Putaala J, Curtze S, Haapaniemi E, Mustanoja S, et al. SMASH-U: a proposal for etiologic classification of intracerebral hemorrhage. Stroke. 2012 Oct;43(10):2592-7. https:// doi.org/10.1161/STROKEAHA.112.661603

20. Yeh SJ, Tang SC, Tsai LK, Jeng JS. Pathogenetical subtypes of recurrent intracerebral hemorrhage: designations by $\mathrm{SMASH}-\mathrm{U}$ classification system. Stroke. 2014 Sep;45(9):2636-42. https://doi. org/10.1161/STROKEAHA.114.005598

21. Kothari RU, Brott T, Broderick JP, Barsan WG, Sauerbeck LR, Zuccarello $\mathrm{M}$, et al. The ABCs of measuring intracerebral hemorrhage volumes. Stroke. 1996 Aug;27(8):1304-5. https://doi.org/10.1161/01.str.27.8.1304

22. Domingues R, Rossi C, Cordonnier C. Diagnostic evaluation for nontraumatic intracerebral hemorrhage. Neurol Clin. 2015 May;33(2):315-28. http://dx.doi.org/10.1016/j.ncl.2014.12.001

23. Zhu XL, Chan MSY, Poon WS. Spontaneous intracranial hemorrhage: Which patients need diagnostic cerebral angiography? A prospective study of 206 cases and review of the literature. Stroke. 1997 Jul;28(7):1406-9. https://doi.org/10.1161/01.str.28.7.1406

24. Morotti A, Dowlatshahi D, Boulouis G, Al-Ajlan F, Demchuk AM, Aviv RI, et al. Predicting intracerebral hemorrhage expansion with noncontrast computed tomography: The BAT score. Stroke. 2018 May;49(5):1163-9. https://doi.org/10.1161/STROKEAHA.117.020138

25. Yao X, Xu Y, Siwila-Sackman E, Wu B, Selim M. The HEP score: a nomogram-derived hematoma expansion prediction scale. Neurocrit Care. 2015 Oct;23(2):179-87. https://doi.org/10.1007/ s12028-015-0147-4

26. Orito K, Hirohata M, Nakamura Y, Takeshige N, Aoki T, Hattori G, et al. Leakage sign for primary intracerebral hemorrhage a novel predictor of hematoma growth. Stroke. 2016 Apr;47(4):958-63. https://doi. org/10.1161/STROKEAHA.115.011578

27. Li Q, Liu QJ, Yang WS, Wang XC, Zhao LB, Xiong X, et al. Island sign: an imaging predictor for early hematoma expansion and poor outcome in patients with intracerebral hemorrhage. Stroke. 2017 Nov;48(11):3019-25. https://doi.org/10.1161/ STROKEAHA.117.017985

28. Li Q, Yang WS, Wang XC, Cao D, Zhu D, Lv FJ, et al. Blend sign predicts poor outcome in patients with intracerebral hemorrhage. PLoS One. 2017 Aug;12(8):e0183082. https://doi.org/10.1371/journal. pone.0183082

29. Sporns PB, Schwake M, Kemmling A, Minnerup J, Schwindt W, Niederstadt T, et al. Comparison of spot sign, blend sign and black hole sign for outcome prediction in patients with intracerebral hemorrhage. J Stroke. 2017 Sep;19(3):333-9. https://doi. org/10.5853/jos.2016.02061

30. Shimoda Y, Ohtomo S, Arai H, Okada K, Tominaga T. Satellite sign: a poor outcome predictor in intracerebral hemorrhage. Cerebrovasc Dis. 2017;44(3-4):105-12. https://doi.org/10.1159/000477179

31. Deng L, Zhang G, Wei X, Yang WS, Li R, Shen YQ, et al. Comparison of satellite sign and island sign in predicting hematoma growth and poor outcome in patients with primary intracerebral hemorrhage. World Neurosurg. 2019 Jul;127:e818-e825. https://doi.org/10.1016/j. wneu.2019.03.273
32. Gioia LC, Kate M, Choi V, Sivakumar L, Jeerakathil T, Kosior $\mathrm{J}$, et al. Ischemia in intracerebral hemorrhage is associated with leukoaraiosis and hematoma volume, not blood pressure reduction. Stroke. 2015 Jun;46(6):1541-7. https://doi.org/10.1161/ STROKEAHA.114.008304

33. Orakcioglu B, Kentar MM, Schiebel P, Uozumi Y, Unterberg A, Sakowitz OW. Perihemorrhagic ischemia occurs in a volumedependent manner as assessed by multimodal cerebral monitoring in a porcine model of intracerebral hemorrhage. Neurocrit Care. 2015 Feb;22(1):133-9. https://doi.org/10.1007/s12028-014-0027-3

34. Prabhakaran S, Gupta R, Ouyang B, John S, Temes RE, Mohammad $Y$, et al. Acute brain infarcts after spontaneous intracerebral hemorrhage: A diffusion-weighted imaging study. Stroke. 2010 Jan;41(1):89-94. https://doi.org/10.1161/STROKEAHA.109.566257

35. Prabhakaran S, Naidech AM. Ischemic brain injury after intracerebral hemorrhage: a critical review. Stroke. 2012 Aug;43(8):2258-63. https://doi.org/10.1161/STROKEAHA.112.655910

36. Menon RS, Burgess RE, Wing JJ, Gibbons MC, Shara NM, Fernandez $S$, et al. Predictors of highly prevalent brain ischemia in intracerebral hemorrhage. Ann Neurol. 2012 Feb;71(2):199-205. https://doi. org/10.1002/ana.22668

37. Auriel E, Gurol ME, Ayres A, Dumas AP, Schwab KM, Vashkevich $A$, et al. Characteristic distributions of intracerebral hemorrhage-Associated diffusion-weighted lesions. Neurology. 2012 Dec;79(24):2335-41. https://doi.org/10.1212/ WNL.0b013e318278b66f

38. Ye XH, Gao T, Xu XH, Cai JS, Li JW, Liu KM, et al. Factors associated with remote diffusion-weighted imaging lesions in spontaneous intracerebral hemorrhage. Front Neurol. 2018 Apr;9:209. https://doi. org/10.3389/fneur.2018.00209

39. Smith EE, Fitzsimmons AL, Nogueira RG, Singhal AB. Spontaneous hyperacute postischemic hemorrhage leading to death. J Neuroimaging. 2004 Oct;14(4):361-4. https://doi. org/10.1111/j.1552-6569.2004.tb00264.x

40. Jauch EC, Pineda JA, Claude Hemphill III J. Emergency neurological life support: intracerebral hemorrhage. Neurocrit Care. 2015 Dec;23 Suppl 2:S83-93. https://doi.org/10.1007/s12028-015-0167-0

41. Carcel C, Wang X, Sato S, Stapf C, Sandset EC, Delcourt C, et al. Degree and timing of intensive blood pressure lowering on hematoma growth in intracerebral hemorrhage: intensive blood pressure reduction in acute cerebral hemorrhage trial-2 results. Stroke. 2016 Jun;47(6):1651-3. https://doi.org/10.1161/ STROKEAHA.116.013326

42. Arima H, Heeley E, Delcourt C, Hirakawa Y, Wang X, Woodward $\mathrm{M}$, et al. Optimal achieved blood pressure in acute intracerebral hemorrhage: INTERACT2. Neurology. 2015 Feb;84(5):464-71. https:// doi.org/10.1212/WNL.0000000000001205

43. Anderson CS, Heeley E, Huang Y, Wang J, Stapf C, Delcourt C, et al. Rapid blood-pressure lowering in patients with acute intracerebral hemorrhage. N Engl J Med. 2013 Jun;368(25):2355-65. https://doi. org/10.1056/NEJMoa1214609

44. Qureshi Al, Palesch YY, Barsan WG, Hanley DF, Hsu CY, Martin RL, et al. Intensive blood-pressure lowering in patients with acute cerebral hemorrhage. N Engl J Med. 2016 Sep;375(11):1033-43. https://doi.org/10.1056/NEJMoa1603460

45. Frontera JA, Lewin $3^{\text {rd }} \mathrm{JJ}$, Rabinstein AA, Aisiku IP, Alexandrov AW, Cook AM, et al. Guideline for reversal of antithrombotics in intracranial hemorrhage: a statement for healthcare professionals from the Neurocritical Care Society and Society of Critical Care Medicine. Neurocrit Care. 2016 Feb;24(1):6-46. https://doi. org/10.1007/s12028-015-0222-x

46. Pollack Junior CV, Reilly PA, van Ryn J, Eikelboom JW, Glund S, Bernstein RA, et al. Idarucizumab for dabigatran reversal — full cohort analysis. N Engl J Med. 2017 Aug;377(5):431-41. https://doi. org/10.1056/NEJMoa1707278 
47. Connolly SJ, Crowther M, Eikelboom JW, Gibson CM, Curnutte JT, Lawrence JH, et al. Full Study report of andexanet alfa for bleeding associated with factor Xa inhibitors. N Engl J Med. 2019 Apr;380(14):1326-35. https://doi.org/10.1056/NEJMoa1814051

48. Baharoglu MI, Cordonnier C, Salman RA-S, de Gans K, Koopman MM, Brand A, et al. Platelet transfusion versus standard care after acute stroke due to spontaneous cerebral haemorrhage associated with antiplatelet therapy (PATCH): a randomised, open-label, phase 3 trial. Lancet. 2016 Jun;387(10038):2605-13. https://doi.org/10.1016/ S0140-6736(16)30392-0

49. Mayer SA, Brun NC, Begtrup K, Broderick J, Davis S, Diringer MN, et al. Efficacy and safety of recombinant activated factor VII for acute intracerebral hemorrhage. N Engl J Med. 2008 May;358(20):2127-37. https://doi.org/10.1056/NEJMoa0707534

50. Sprigg N, Flaherty K, Appleton JP, Salman RAS, Bereczki D, Beridze M, et al. Tranexamic acid for hyperacute primary IntraCerebral Haemorrhage ( $\mathrm{TICH}-2)$ : an international randomised, placebo-controlled, phase 3 superiority trial. Lancet. 2018 May;391(10135):2107-15. https://doi.org/10.1016/S01406736(18)31033-X

51. Mendelow AD, Gregson BA, Rowan EN, Murray GD, Gholkar A, Mitchell PM, et al. Early surgery versus initial conservative treatment in patients with spontaneous supratentorial lobar intracerebral haematomas (STICH II): a randomised trial. Lancet. 2013;382(9890):397-408. https:// doi.org/10.1016/S0140-6736(13)60986-1

52. Hanley DF, Thompson RE, Rosenblum M, Yenokyan G, Lane K, McBee $\mathrm{N}$, et al. Efficacy and safety of minimally invasive surgery with thrombolysis in intracerebral haemorrhage evacuation (MISTIE III): a randomised, controlled, open-label, blinded endpoint phase 3 trial. Lancet. 2019 Mar;393(10175):1021-32. https://doi.org/10.1016/ S0140-6736(13)60986-1

53. Pontes-Neto OM, Oliveira-Filho J, Valiente R, Friedrich M, Pedreira B, Rodrigues BCB, et al. Diretrizes para o manejo de pacientes com hemorragia intraparenquimatosa cerebral espontânea. Arq NeuroPsiquiatr. 2009 Aug;67(3B):940-50. https://doi.org/10.1590/S0004282X2009000500034

54. Hemphill III JC, Bonovich DC, Besmertis L, Manley GT, Johnston SC. The ICH score. A simple, reliable grading scale for intracerebral hemorrhage. Stroke. 2001 Apr;32(4):891-7. https://doi. org/10.1161/01.STR.32.4.891

55. Becker KJ, Baxter AB, Cohen WA, Bybee HM, Tirschwell DL, Newell DW, et al. Withdrawal of support in intracerebral hemorrhage may lead to self-fulfilling prophecies. Neurology. 2001 Mar;56(6):766-72. https://doi.org/10.1212/wnl.56.6.766 